\title{
The Development of Community Based Guidelines for 0-5 Aged Children Detection and Stimulation
}

\author{
Nur Hayati, Atien Nur Chamidah, Arumi Savitri Fatimaningrum
}

Yogyakarta State of University, Yogyakarta, Indonesia

e-mail: nurhayati@uny.ac.id

\begin{abstract}
The objective of the research was to produce guidelines to detect and stimulate the development of children aged $0-5$ for parents, health cadres, and early childhood education teachers. The research was the continuance of previous research about guideline in detecting the development of children aged 0-3. It was also aimed at optimizing the detection on growth and development of early-aged children in playgroups and kindergartens. The study used R \& D (Research and Development) design carried out for two (2) years. The research in the first year covered 3 steps: 1) arrangement the draft of the guideline for children aged 0-5 based on the needs from parents, health cadres, and early childhood education teachers, 2) try out of guideline validation through expert of children development and of learning media, and 3) limited try out to parents, health cadres, and early childhood education teachers. The data, both qualitative and quantitative, was converted into descriptive analysis based on the interview and forum group discussion. The final research result showed that the design of guidelines to detect and stimulate the development of children aged 0-5 was compatible for parents, health cadres, and early childhood education teachers. This also could be used as a guideline if there was tardiness in the children's development.
\end{abstract}

Keywords: Detection, stimulation, early childhood development, community based

\section{INTRODUCTION}

The growth occurred in early childhood is a very important development in each individual. Child development begins with biological, cognitive and socioemotic processes consisting of pre-birth period, infancy, early childhood, middle and late childhood [13]. The processes occurred during the development period are interrelated and possible to gain a good influence from within the self and the environment around the child.

Early childhood can be categorized as a child who is in infancy and early childhood. As stated in Permendikbud Number 84 Year 2014, early childhood is at the age of 0 to 6 years [10]. The early age of the childhood is a very important time to get a lot of stimulation and information. The first stage of human development is referred to as the "absorbing brain" period which starts from birth to age 6 [12]. Children in that period absorb information and build concepts about the reality that they face. On the brain pathways of children's brain at the early age, it is growing quite rapidly so it strongly supports communication process, understanding, social and emotional development of the children at the next age [7]. The ability appeared at one stage of the developmental age of the child can support growth and development in the next stage of age.

Detection conducted from an early age is very useful to predict and prevent the existence of problems at the next age [16]. The detection of parents for their children can be done by looking at the behavior of children in their daily activity. The effectiveness of parent-integrated assessments on all childs' needs is useful in preventing potential hazards or problems[8].

The World Health Organization (WHO) states that sensory stimulation is important in the early years of life to achieve an optimal development of the child [1]. Good parenting is characterized by a healthy home environment, child mortality, child responsiveness and stimulation of children by giving them opportunities to play and explore [4]. When playing, children can learn many things and it can become the foundation for building the concept of knowledge. Environment is a secondary factor that can support or hamper child development[12]. Thus, the stimulation provided through activities becomes the child's foothold to achieve the development according to the stage.

Guidelines for detection and stimulation have not been widely found in the community. A 
study found that one of the obstacles in the implementation of child development detection by health cadres was the availability of guidebooks that can be used for them in assessing the child development [2]. So far, the available books are only health manuals and cadre handbooks obtained from Health Center. Nevertheless, cadres have difficulty using those manuals because they are less easily understood by cadres who have variety of educational backgrounds.

Book of Detection and Stimulation of Development of 0-36 months old children that have been developed can be used by health cadre as a guide in observing child development in accordance with validated standard [2]. This handbook is expected to facilitate the health cadre in observing the child in order to be known early if there is a child with special needs who need immediate assistance to be referred to a more competent expert.

Based on the background of the problem, the monitoring of child development will be optimal if it is supported by parents, health cadres and early childhood educators. This can be started from a study that can produce guidelines for the detection and stimulation of the early childhood development based on the community that is for parents, health cadres and early childhood educators. Principles in the compiling of this early childhood detection and development guidance manual are based on the needs that exist in the field so that it is so easily understood and used by parents and health cadres who still have a minimal knowledge about an early childhood.

The growth of the child development detection and stimulation guidance in this study was designed for children aged 0-5 years. Efforts to develop guidelines for detection and stimulation are tailored to the early childhood stages in the 0-6 year age range. Children at that age experience a period of growth and development with a very striking increase, so that the detection and stimulation of the people closest facilitate them to achieve the development in accordance with the stages of their age which are easily observed by parents. However, during this monitoring the growth and development of children are coordinated through the role of the community and the Posyandu program. The need for early childhood detection and stimulation guidance for parents and health cadres is essential in order to monitor early childhood development appropriately according to the age stage. With the guidebook detection and stimulation of early childhood development for parents and cadres Posyandu, it can be a solution for the limited time and distance to coordinate with the Health Center.

\section{METHODS}

This study was designed as a multi-year study conducted in two years. This study used a Research and Development approach that refers to the model design of Borg and Gall, which is a development model that produces a particular product [5]. The product of this first year study will produce guidelines for early childhood detection and stimulation in the form of books for parents, health cadres and early childhood educators. The research steps at this stage are clearly illustrated in the following scheme:

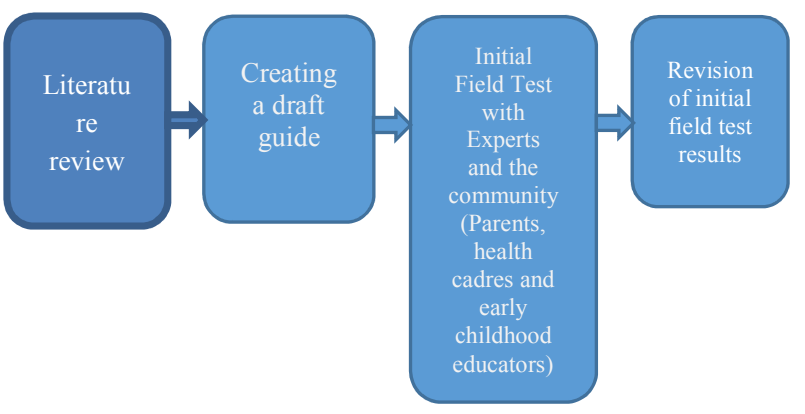

Figure 1. Research Steps at this Stage

Based on the figure above, the research steps can be explained that in this first stage the researchers conducted exploratory literature studies. The next step is to develop a guidebook about the detection and stimulation of the development of children aged 0-5 years. Following the design of the final guide, field trials were conducted on subjects consisting of child development experts, media experts, parents, health cadres, and early childhood educators. The last step is to revise the results of the initial field test and produce guidance book detection and stimulation of development of children aged 0-5 years.

\section{RESULTS AND DISCUSSION}

\subsection{Research Result}

This research on the development of guidelines for the detection and stimulation of early childhood development of the community has resulted two stages. The result of the first phase of this study is in the form of literature review and in the second phase is the draft design guidelines for 
the detection and stimulation of development of children aged $0-5$ years.

\subsubsection{Results of the Review Literature}

The literature study was conducted in exploratory referring to the early detection of toddler-growing books of Surya Kanti Foundation and Permendikbud Number 137, 2014 about the standard of achievement of children [9,11]. The result of the literature study on early detection of toddlers' development has been found that the aspects of detected development consist of aspects of gross movement, smooth movement, observation, speech and socialization. The aspects of development based on the standard of achievement level of child development consist of religious and moral values, physical-motor (soft motor and rough motor), cognitive, language, social emotional and art.

The next stage of the research after an exploratory literature study is doing the FGD (Focus Group Discussion) with experts in the field of medicine, psychology and education of early childhood. The result of the discussion is that the development of guidelines for the detection and stimulation of the development of children aged 0-5 years is the motor aspects of coarse (MK), soft motor $(\mathrm{MH})$, cognitive $(\mathrm{K})$, language $(\mathrm{B})$, and socialization (S). The stages of detection and developmental stimulation are divided into eleven (11) stages of age group which are age 0-3 months, 3-6 months, 6-9 months, 9-12 months, 12-15 months, 15-18 months, 18- 24 months, 24-36 months, 36-48 months, 48-60 months and 60-72 months.

\subsubsection{The Draft of Guidelines for the Detection and Stimulation of the Development of Children 0-5 Years}

The design of the detection and stimulation guidebook for the development of children 0-5 this year consists of two parts: the systematic use of guidebooks and the components of child development detection and stimulation. Systematic guidebooks are designed to facilitate health cadres, parents and early childhood educators as users in order to detect and stimulate the child development. The system is made as simple as possible to make it easier to understand the intent of the author since the users probably have different educational backgrounds. The components of detection and stimulation of child development are made to describe the existence of several stages of development that should reach the children according to their age. Furthermore, from the results of the detection, it can be explained that the stimulation can be given by cadres or parents or educators of early childhood.

\subsubsection{The Systematics Guidebook for Detection and Stimulation of Development of Children 0-5 Years}

This guidebook is used to detect or find possible deviations in children aged $0-5$ years. The subsequent efforts after comprehensive detection can be stimulated to arouse an optimal child development.

The systematic use of this guidebook begins with an observation step, then detection, stimulation and ends by drawing conclusions to determine whether there should be a reference or not to get further treatment.

Table 1. The Systematic Guidebook for Detection and Stimulation of Development of 0-5 Years Old Children

\begin{tabular}{|l|l|}
\hline Component & \multicolumn{1}{|c|}{ Description } \\
\hline Observation & $\begin{array}{l}\text { It is the first stage in observing the child } \\
\text { according to the stage of development. In } \\
\text { addition, in this section there is also an } \\
\text { information about the tools needed in } \\
\text { observing the child development. }\end{array}$ \\
\hline Detection & $\begin{array}{l}\text { It contains the results of observations. In } \\
\text { this section we describe the steps to } \\
\text { evaluate or recognize the stage of } \\
\text { development that the child has achieved. }\end{array}$ \\
\hline Stimulation & $\begin{array}{l}\text { It describes the steps that can be done to } \\
\text { provide stimulation of child development } \\
\text { at every stage of age. This is especially } \\
\text { true for children who have not } \\
\text { demonstrated appropriate abilities at these } \\
\text { stages. }\end{array}$ \\
\hline Conclusion & $\begin{array}{l}\text { It is filled by cadres or parents or early } \\
\text { childhood educators if there are obstacles } \\
\text { in child development. The next stage is } \\
\text { then referred to the related parties by } \\
\text { filling the reference sheet located at the } \\
\text { end of this book. }\end{array}$ \\
\hline Sheet & $\begin{array}{l}\text { It contains advice or therapies to external } \\
\text { stakeholders to address the child } \\
\text { developmental impediments. }\end{array}$ \\
\hline
\end{tabular}


Parents, cadres and early childhood educators can begin observations according to the observation steps. The examiner then scrutinizes the detection sheet to determine whether the child has reached the appropriate stage of development. If an unfilled detection aspect is detected, cadres, parents and teachers can provide stimulation according to the stimulation steps listed in the guidebook. Furthermore, if a health cadre is needed, the child can be inferred to the Health Center to get further treatment.

\subsubsection{Detection and Stimulation Components of 0-5 Years of Age}

The detection and stimulation component in this study cover 5 areas of early childhood development which are aspects of rough motoric, soft motoric, language, socialization and cognition. The complete explanation can be seen from the following table:

Table 2. Rough Motor Development Aspects

\begin{tabular}{|c|c|}
\hline Age & Assessment Component \\
\hline $\begin{array}{l}0-3 \\
\text { months }\end{array}$ & $\begin{array}{l}\text { The child can lift his head upright in the } \\
\text { prone position }\end{array}$ \\
\hline $\begin{array}{l}3-6 \\
\text { months }\end{array}$ & The child can turn from his prone position \\
\hline $\begin{array}{l}6-9 \\
\text { months }\end{array}$ & The child can sit alone \\
\hline $\begin{array}{l}9-12 \\
\text { months }\end{array}$ & $\begin{array}{l}\text { The child can stand on his own and walk } \\
\text { while holding on }\end{array}$ \\
\hline $\begin{array}{l}12-15 \\
\text { months }\end{array}$ & The child can walk back and tiptoe \\
\hline $\begin{array}{l}15-18 \\
\text { months }\end{array}$ & The child can slap the ball \\
\hline $\begin{array}{l}18-24 \\
\text { months }\end{array}$ & Children can jump and push toys with legs \\
\hline $\begin{array}{l}24-36 \\
\text { months }\end{array}$ & $\begin{array}{l}\text { The child can throw the ball, catch the ball } \\
\text { and tiptoe }\end{array}$ \\
\hline \multirow[t]{2}{*}{$\begin{array}{l}36-48 \\
\text { months }\end{array}$} & $\begin{array}{l}\text { Children can walk on a board that is wide } \\
\text { enough }\end{array}$ \\
\hline & $\begin{array}{l}\text { The child can jump down from a height of } \\
\text { approximately } 20 \mathrm{~cm}\end{array}$ \\
\hline $\begin{array}{l}48-60 \\
\text { months }\end{array}$ & $\begin{array}{l}\text { The child can make moves with direction } \\
\text { and coordination, such as jumping, running, } \\
\text { catching, and throwing. }\end{array}$ \\
\hline \multirow[t]{3}{*}{$\begin{array}{l}60-72 \\
\text { months }\end{array}$} & $\begin{array}{l}\text { The child is able to perform physical games } \\
\text { with the rules }\end{array}$ \\
\hline & $\begin{array}{l}\text { Skilled children use the right hand and left } \\
\text { hand }\end{array}$ \\
\hline & $\begin{array}{l}\text { Children are able to perform activities of } \\
\text { personal hygiene }\end{array}$ \\
\hline
\end{tabular}

Table 3. Soft Motor Development Aspects

\begin{tabular}{|c|c|}
\hline \multirow{2}{*}{\multicolumn{2}{|c|}{ Assessment Comnonent }} \\
\hline Age & \\
\hline $\begin{array}{l}0-3 \\
\text { months }\end{array}$ & Eyes and heads follow moving objects \\
\hline $\begin{array}{l}3-6 \\
\text { months }\end{array}$ & $\begin{array}{l}\text { The child can hold the object with both } \\
\text { hands }\end{array}$ \\
\hline $\begin{array}{l}6-9 \\
\text { months }\end{array}$ & $\begin{array}{l}\text { The child can hold the toy with the entire } \\
\text { surface of the hand }\end{array}$ \\
\hline $\begin{array}{l}9-12 \\
\text { months }\end{array}$ & Children can arrange blocks or boxes \\
\hline $\begin{array}{l}12-15 \\
\text { months }\end{array}$ & $\begin{array}{l}\text { Children can play blocks by inserting and } \\
\text { removing objects }\end{array}$ \\
\hline $\begin{array}{l}15-18 \\
\text { months }\end{array}$ & $\begin{array}{l}\text { Children can make sequences of beads / } \\
\text { buttons }\end{array}$ \\
\hline $\begin{array}{l}18-24 \\
\text { months }\end{array}$ & $\begin{array}{l}\text { The child can make a form of various } \\
\text { plastisin }\end{array}$ \\
\hline \multirow[t]{2}{*}{$\begin{array}{l}24-36 \\
\text { months }\end{array}$} & $\begin{array}{l}\text { The child is able to stick a piece of paper or } \\
\text { cloth on a pattern }\end{array}$ \\
\hline & $\begin{array}{l}\text { The child is able to insert the rope in the } \\
\text { bead hole or straw or perforated paper }\end{array}$ \\
\hline \multirow[t]{2}{*}{$\begin{array}{l}36-48 \\
\text { months }\end{array}$} & $\begin{array}{l}\text { The child can insert a small object into a } \\
\text { bottle }\end{array}$ \\
\hline & $\begin{array}{l}\text { The child can cut paper following a straight } \\
\text { line pattern }\end{array}$ \\
\hline $\begin{array}{l}48-60 \\
\text { months }\end{array}$ & $\begin{array}{l}\text { The child is capable of performing } \\
\text { manipulative movements to produce } \\
\text { something, such as drawing, plastisin, } \\
\text { origami }\end{array}$ \\
\hline \multirow[t]{3}{*}{$\begin{array}{l}60-72 \\
\text { months }\end{array}$} & $\begin{array}{l}\text { The child is able to draw according to his } \\
\text { ideas }\end{array}$ \\
\hline & Children are able to cut according to pattern \\
\hline & $\begin{array}{l}\text { The child is able to use the stationery } \\
\text { correctly }\end{array}$ \\
\hline
\end{tabular}

Table 4. Aspects of Cognitive Development

\begin{tabular}{|c|c|}
\hline Age & $\begin{array}{c}\text { Assessment Component } \\
\end{array}$ \\
\hline $\begin{array}{l}0-3 \\
\text { months }\end{array}$ & $\begin{array}{l}\text { Child can recognize the face of the nearest } \\
\text { person }\end{array}$ \\
\hline $\begin{array}{l}3-6 \\
\text { months }\end{array}$ & $\begin{array}{l}\text { The child can listen to the sounds around } \\
\text { him }\end{array}$ \\
\hline $\begin{array}{l}6-9 \\
\text { months }\end{array}$ & $\begin{array}{l}\text { The child can observe various moving } \\
\text { objects }\end{array}$ \\
\hline $\begin{array}{l}9-12 \\
\text { months }\end{array}$ & Children can understand simple commands \\
\hline $\begin{array}{l}12-15 \\
\text { months }\end{array}$ & The child can name the object \\
\hline $\begin{array}{l}15-18 \\
\text { months }\end{array}$ & Children can name their own \\
\hline $\begin{array}{l}18-24 \\
\text { months }\end{array}$ & $\begin{array}{l}\text { The child can use the game equipment in an } \\
\text { irregular manner }\end{array}$ \\
\hline \multirow[t]{2}{*}{$\begin{array}{l}24-36 \\
\text { months }\end{array}$} & $\begin{array}{l}\text { Children can mimic people's activities at } \\
\text { home }\end{array}$ \\
\hline & The child can name the limbs \\
\hline \multirow[t]{2}{*}{$\begin{array}{l}36-48 \\
\text { months }\end{array}$} & $\begin{array}{l}\text { The child can recognize the missing part of } \\
\text { an image pattern }\end{array}$ \\
\hline & The child can name a few letters \\
\hline $48-61$ & The child can classify and sort objects \\
\hline
\end{tabular}




\begin{tabular}{|l|l|}
\hline months & $\begin{array}{l}\text { Children can recognize symbols of numbers } \\
\text { and letters }\end{array}$ \\
\hline $\begin{array}{l}60-72 \\
\text { months }\end{array}$ & $\begin{array}{l}\text { Children can classify objects by color, shape } \\
\text { and size }\end{array}$ \\
\cline { 2 - 2 } & $\begin{array}{l}\text { The child is able to recognize the cause of } \\
\text { the environment (for example, water causes } \\
\text { something to become wet) }\end{array}$ \\
\cline { 2 - 2 } & $\begin{array}{l}\text { The child can match numbers with the } \\
\text { symbols 1-20 numbers }\end{array}$ \\
\hline
\end{tabular}

Table 5. Aspects of Language Development

\begin{tabular}{|c|c|}
\hline Age & Assessment Component \\
\hline $\begin{array}{l}0-3 \\
\text { months }\end{array}$ & $\begin{array}{l}\text { Babbling spontaneously or reacting with } \\
\text { babbling }\end{array}$ \\
\hline $\begin{array}{l}3-6 \\
\text { months }\end{array}$ & Imitating sounds or words \\
\hline $\begin{array}{l}6-9 \\
\text { months }\end{array}$ & Saying $m a \ldots m a \ldots p a \ldots p a \ldots$ \\
\hline $\begin{array}{l}9-12 \\
\text { months }\end{array}$ & $\begin{array}{l}\text { Spelling a word or more and understand } \\
\text { what it means }\end{array}$ \\
\hline $\begin{array}{l}12-15 \\
\text { months }\end{array}$ & $\begin{array}{l}\text { Mentioning the body part by composing } \\
\text { two words }\end{array}$ \\
\hline $\begin{array}{l}15-18 \\
\text { months }\end{array}$ & $\begin{array}{l}\text { The child mentions the names of the } \\
\text { pictures in the book / magazine, at least } \\
\text { by composing two words }\end{array}$ \\
\hline $\begin{array}{l}18-24 \\
\text { months }\end{array}$ & Telling about what he saw \\
\hline \multirow[t]{4}{*}{$\begin{array}{l}24-36 \\
\text { months }\end{array}$} & $\begin{array}{l}\text { The child is able to recognize the name } \\
\text { of the object from the picture }\end{array}$ \\
\hline & The child is able to name his own \\
\hline & $\begin{array}{l}\text { The child is able to name his family } \\
\text { members }\end{array}$ \\
\hline & $\begin{array}{l}\text { Children are able to do other peoples' } \\
\text { commands }\end{array}$ \\
\hline \multirow[t]{2}{*}{$\begin{array}{l}\text { 36-48 } \\
\text { months }\end{array}$} & $\begin{array}{l}\text { The child begins to understand the two } \\
\text { commands simultaneously (grabing the } \\
\text { toys and giving them to the sister) }\end{array}$ \\
\hline & $\begin{array}{l}\text { The child can express his wishes with a } \\
\text { simple sentence }\end{array}$ \\
\hline \multirow[t]{4}{*}{$\begin{array}{l}48-62 \\
\text { months }\end{array}$} & $\begin{array}{l}\text { The child is able to understand the story } \\
\text { or the other person's command }\end{array}$ \\
\hline & $\begin{array}{l}\text { Children are able to make and answer } \\
\text { questions according to simple sentences }\end{array}$ \\
\hline & $\begin{array}{l}\text { The child expresses an opinion or gives } \\
\text { a reason for something to be desired or } \\
\text { disagreed }\end{array}$ \\
\hline & $\begin{array}{l}\text { Recounting experiences or stories ever } \\
\text { heard }\end{array}$ \\
\hline \multirow[t]{3}{*}{$\begin{array}{l}60-72 \\
\text { months }\end{array}$} & $\begin{array}{l}\text { Children can understand the concept in } \\
\text { a story book }\end{array}$ \\
\hline & $\begin{array}{l}\text { The child is able to name words that } \\
\text { have the same initial letter sounds }\end{array}$ \\
\hline & $\begin{array}{l}\text { The child is able to compose simple } \\
\text { sentences with the S-P-O pattern }\end{array}$ \\
\hline
\end{tabular}

\begin{tabular}{|c|c|}
\hline & The child can write his own name \\
\hline \multicolumn{2}{|r|}{ Table 6. Social Development Aspects } \\
\hline Age & Assessment Component \\
\hline $\begin{array}{l}0-3 \\
\text { months }\end{array}$ & Smiling when talking / smiling \\
\hline $\begin{array}{l}3-6 \\
\text { months }\end{array}$ & Trying to reach objects that are nearby \\
\hline $\begin{array}{l}6-9 \\
\text { months }\end{array}$ & Playing 'peek-ba' \\
\hline $\begin{array}{l}9-12 \\
\text { months }\end{array}$ & $\begin{array}{l}\text { The child can provide toys to the } \\
\text { examiner }\end{array}$ \\
\hline $\begin{array}{l}12-15 \\
\text { months }\end{array}$ & $\begin{array}{l}\text { Imitating housework while taking care } \\
\text { of the doll }\end{array}$ \\
\hline $\begin{array}{l}15-18 \\
\text { months }\end{array}$ & Playing with peers \\
\hline \multirow[t]{3}{*}{$\begin{array}{l}18-24 \\
\text { months }\end{array}$} & $\begin{array}{l}\text { Dressing and buttoning their own } \\
\text { clothes }\end{array}$ \\
\hline & Playing interactive with friends \\
\hline & The child can separate from parents \\
\hline $\begin{array}{l}24-36 \\
\text { months }\end{array}$ & Children can wear their own clothes \\
\hline \multirow{2}{*}{$\begin{array}{l}36-48 \\
\text { months }\end{array}$} & The child is patient waiting for his turn \\
\hline & $\begin{array}{l}\text { The child begins to express a regretful } \\
\text { expression when he passes }\end{array}$ \\
\hline
\end{tabular}

Based on Table 2 to Table 6 , it can be seen that each stage of the age of 0-5 years old child has a distinctive development in every aspect. Parents, health cadres and early childhood educators can do the stimulation according to the guidelines. Stimulation are providing colorful toys so that children can recognize colors, providing puzzle toys so that they are motivated to solve problems from the pieces of the puzzle, inviting them to play up and down stairs or jump rope so that their motoric skill can improve. A variety of play and game activities must be related to the purpose of stimulation so that it can develop the 5 aspects of child development.

\subsection{DISCUSSION}

The development of children aged 0-5 years has a uniqueness because the behavior aroused among the children is different. Prevention efforts, stimulation efforts and healing efforts as early as possible are necessary so that their growth can be achieved optimally [7]. Detection activity and stimulation of child development are now expected to be done by all people since the number of health workers and educators of early childhood are very limited. 
The number of under-fives in D.I Yogyakarta in 2016 was 140,719 boys and 134,691 girls, while the ratio of Healt Center per 30,000 population in 2016 was 0.98 [6]. Thus it can be concluded that the detection of early childhood development cannot be done all by health personnel. Parents, health cadres and early childhood educators as community members can take a role to detect their children according to the stage of age development. Observations often made by parents during interacting with their children are very important to recognize the problems that arise in the behavior of children [14]. The participation done by parents, health cadres and early childhood educators can speed up the handling if there are any discrepancies or delays in child development.

Stimulation given to children from an early age can lead parents to be more sensitive to their children development and respond easily to behaviors that children emerge at any time [17]. Parents can observe the responses that children generate in the form of their body movements and language expression. The stimulation can be given through playful activities. Playing activities in accordance with the stages of child development is very useful to optimize the child development[17].

Any information the children receive through their environment will be responded by the brains' nerves so that the more stimuli it receives the more intelligent the children are and it supports their lives [3]. The benefits gained when playing are stimulating children development in the cognitive, social and interpersonal aspects [15]. Thus the stimulation given as early as possible will make children more intelligent and prepare them for development at the next age.

Research development of guidance detection and stimulation of development of children aged 0-5 years is expected to make community stand alone in observing the development of children so that they can help the government to optimize child development. Detection and stimulation are very useful to anticipate if there are any delays in child development. Thus the barriers occurred do not take too long in preventing children to achieve their growth and development in accordance with their age.

\section{CONCLUSIONS}

The compiling of detection and stimulation guidebook of child development aged 0-5 years was conducted because of the need in the field about a guidebook that was easy to understand and used by health cadres. This guidebook is also needed by parents and educators of early childhood so that they are be able to observe the development of child at any time, since the main duty of parenting is in the hands of parents. The results of this study consist of two stages which are the literature review stage and the compiling stage of the guidebook design. The results of the review literature conclude that the developmental aspects observed in this guide are rough motoric aspects, soft motor aspects, language aspects, socialization aspects and cognitive aspects. The design of guidebook of detection and stimulation of development of children aged $0-5$ years is in the form of systematic use of the manual which starts from: (1) observation; (2) detection; (3) stimulation; (4) conclusion and (5) making referrals to the Health Center or the competent authorities. The components of detected child development age are age 0-3 months, 3-6 months, 6-9 months, 9-12 months, 12-15 months, 15-18 months, 18-24 months, 24-36 months, 36 -48 months, and 48-72 months. The compiling of this guidebook of detection and stimulation of development of child aged $0-5$ years is expected to be the easiest guide to optimize the child development. In addition, it can also be considered as a quick guide to overcome the delays that arise in the development of child.

\section{REFERENCES}

[1] Avan B.I, Raza S.A, Kirkwood B.R, (2013), A community-based study of early childhood sensory stimulation in home environment associated with growth and psychomotor development in Pakistan, Int J Public Health, DOI 10.1007/s00038-013-0525-7

[2] Ayriza, Y., Hayati, Nur., Fatimaningrum, A.S., Chamidah, A.N., (2014), Pengembangan panduan deteksi dan stimulasi perkembangan anak usia dini bagi kader posyandu, Laporan penelitian Lembaga Penelitian dan Pengabdian kepada Masyarakat Universitas Negeri Yogyakarta, Yogyakarta

[3] Berk, L.E., (2009), Exploring lifespan development, p 93, Pearson Education Inc, Boston

[4] Black, M.M., et all, (2016), Early childhood development coming of age: science through the life course, Lancet series,http://dx.doi.org/10.1016/ S01406736(16)31389-7 
[5] Borg, W. R. \& Gall, M. D. (1983). Educational research: An introduction. New York: Longman.

[6] Didik Budijanto et all, (2016), Data dan informasi profil kesehatan Indonesia, Pusat Data dan Informasi Kementerian Kesehatan RI 2017, Jakarta, Available at: http://www.depkes.go.id/resources/download/p usdatin/lain-lain/Data dan Informasi Kesehatan Profil Kesehatan Indonesia 2016 - smaller size - web.pdf

[7] Fatimaningrum, A.S., Ayriza, Y., Hayati, N., (2015), Chamidah, A.N., The development of guidelines for early childhood detection and stimulation for health cadres, Proceeding international conference of all care for children on early childhood development, Surabaya, Indonesia June $12^{\mathrm{TH}}-13^{\mathrm{TH}}$ 2015, ISBN:978979-028-742-6

[8] Frongillo, E.A., Tofail, F., Hamadani, J.D., Warren, A.M., dan Mehrin, S.F, (2014), Measures and indicators for assessing impact of interventions integrating nutrition, health, and early childhood development, Ann. N.Y. Acad. Sci. 1308, pp.68-88, Doi: 10.1111/nyas. 12319 .

[9] Masduki,S., Wibowo, C.S., Alisjahbana, A., Wickens, R., Daigle, G., Pakpahan,M.N., (2003), Deteksi dini tumbuh kembang balita, Surya Kanti, Bandung

[10] Menteri Pendidikan dan Kebudayaan Republik Indonesia, (2014), Peraturan menteri pendidikan dan kebudayaan republik indonesia nomor 84 tahun 2014 tentang pendirian satuan pendidikan anak usia dini, Jakarta, Available at:Permendikbud-nomor-084-tahun-2014-ttijin-pendirian-paudni.pdf

[11] Menteri Pendidikan dan Kebudayaan Republik Indonesia, (2014), Peraturan menteri pendidikan dan kebudayaan republik indonesia nomor 137 tahun 2014 tentang standar nasional pendidikan anak usia dini, Jakarta, Available at:

http://disdik.banjarbarukota.go.id/produk huku m/Permendikbud $\% 20$ Standar $\% 20$

Nasional\%20PAUD.pdf

[12] Montessori, M., (2013), Metode montessori, p 79-187, Pustaka Pelajar, Yogyakarta

[13] Santrock, J.W., (2012), Life span development perkembangan masa hidup ed 13 book $1, \mathrm{p}$ 18, Erlangga, Jakarta

[14] Smeekens, S., Riksen, J.M., Walraven, Hedwig, J.A., Bakel, V., (2007), Multiple Determinants of Externalizing Behavior in 5-
Year-Olds: A Longitudinal Model, Published online: 23 January 2007C Springer Science+Business Media, LLC 2007 J Abnorm Child Psychol (2007) 35:347-361, DOI 10.1007/s10802-006-9095-y.

[15] Theobald, M., et all, (2015), Children's Perspectives of Play and Learning for Educational Practice, Education sciences ISSN 2227-7102, 5, 345-362, doi:10.3390/educsci5040345

[16] Veldhuizen, (2016), Systematic Screening for Developmental Delay in Early Childhood: Problems and Possible Solutions, Curr Dev Disord Rep 3:184-189, DOI 10.1007/s40474-016-0090-X

[17] Yousafzai, A.K., Rasheed, M.A., Rizvi, A., Amstrong, R., Bhutta, Z.A., (2014), Effect of integrated responsive stimulation and nutrition interventions in the Lady Health Worker programme in Pakistan on child development, growth, and health outcomes: a clusterrandomised factorial eff ectiveness trial, Lancet; 384: 1282-93, doi.org/10.1016/S01406736(14)60455-4 